\title{
Erratum to: Community-based pediatric palliative care for health related quality of life, hospital utilization and costs lessons learned from a pilot study
}

Jeffrey Goldhagen ${ }^{1}$, Mark Fafard ${ }^{2 *}$, Kelly Komatz ${ }^{1}$, Terry Eason ${ }^{3}$ and William C. Livingood ${ }^{4}$

\section{Erratum}

Upon publication of the original article [1], minor errors were noticed in the Article Title. This has now been corrected in this erratum. Instead of:

"Community-based pediatric palliative care for health related quality of life, hospital utilization and costs lessons learned from a pilot study"

The Title should read:

"The impact of community-based palliative care on health related quality of care, hospital utilization and costs: Lessons learned from a pilot study"

\section{Author details}

'Division of Community and Societal Pediatrics, Department of Pediatrics, UF College of Medicine - Jacksonville, 841 Prudential Drive, Suite $1330 \mathrm{~m}$, Jacksonville, FL 32207, USA. ${ }^{2}$ Baptist Health Research Institute, Baptist Health System, 836 Prudential Drive, Pavilion 6th Floor, Jacksonville, FL 32207, USA. ${ }^{3}$ Community PedsCare, Community Hospice of Northeast Florida, 4266 Sunbeam Rd., Jacksonville, FL 32257, USA. ${ }^{4}$ Center for Health Equity and Quality Research, UF College of Medicine-Jacksonville, 580 W. 8th St., Tower II, Room 6015, Jacksonville, FL 32209, USA.

Received: 9 September 2016 Accepted: 9 September 2016 Published online: 15 September 2016

\section{Reference}

1. Goldhagen J, Fafard M, Komatz K, Eason T, Livingood WC. Community-based pediatric palliative care for health related quality of life, hospital utilization and costs lessons learned from a pilot study. BMC Palliat Care. 2016;15:73. doi:10.1186/s12904-016-0138-z.

\footnotetext{
* Correspondence: Mark.Fafard@bmcjax.com

${ }^{2}$ Baptist Health Research Institute, Baptist Health System, 836 Prudential

Drive, Pavilion 6th Floor, Jacksonville, FL 32207, USA

Full list of author information is available at the end of the article

Submit your next manuscript to BioMed Central and we will help you at every step:

- We accept pre-submission inquiries

- Our selector tool helps you to find the most relevant journal

- We provide round the clock customer support

- Convenient online submission

- Thorough peer review

- Inclusion in PubMed and all major indexing services

- Maximum visibility for your research

Submit your manuscript at www.biomedcentral.com/submit 